\title{
Cytotoxic potential of sponge extracts from Mauritius Waters on human cancer cell lines
}

\author{
Prerna Roy $^{1}$, Avin Ramanjooloo ${ }^{*}$, Jay Rovisham Singh Doorga ${ }^{1}$, Girish Beedessee ${ }^{1}$, Thierry Cresteil ${ }^{2}$, Rob WM Van Soest ${ }^{3}$ and Daniel EP \\ Marie $^{1}$
}

${ }^{1}$ Mauritius Oceanography Institute, Avenue des Anchois, Morcellement de Chazal, Albion, Mauritius

${ }^{2}$ Institut de Chimie des Substances Naturelles, CNRS UPR 2301, Centre de Recherche de Gif, Gif sur Yvette, France

${ }^{3}$ Netherlands Centre for Biodiversity Naturalis, Leiden, The Netherlands

\begin{abstract}
In the search of bioactive compounds from marine sponges from Mauritius Waters, a preliminary cytotoxic assessment of their extracts was conducted. Marine sponges are important sources of secondary metabolites with the potential of treating human diseases such as cancer, a range of viral diseases, Alzheimer, malaria, and inflammations. The ethyl acetate, hexane and methanol extracts obtained from 26 species were evaluated at $50 \mu \mathrm{g} / \mathrm{mL}$ by MTT assay on HeLa, KB and HL-60 cancer cells. Statistical analysis showed that the ethyl acetate extracts had an average of $56.7 \%$ cytotoxicity and were more potent than hexane (44.2\%) and methanol (33.4\%) extracts. Further studies by MTS assay of selected extracts on KB cells showed $\mathrm{IC}_{50}$ values of $0.48 \mu \mathrm{g} / \mathrm{mL}, 85 \mathrm{ng} / \mathrm{mL}$ and $0.5 \mathrm{ng} / \mathrm{mL}$ for Biemna tubulata (BTUE), Epipolasis suluensis (ESE) and Hyrtios sp (HYSE) respectively. The $\mathrm{IC}_{50}$ values of BTUE, ESE and HYSE on HL-60 cells were $1.44 \mu \mathrm{g} / \mathrm{mL}, 2.28 \mu \mathrm{g} /$ $\mathrm{mL}$ and $1.3 \mathrm{ng} / \mathrm{mL}$ respectively. HYSE was more active that BTUE and $\mathrm{ESE}$ as it displayed $\mathrm{IC}_{50}$ values at nano-level concentrations on KB and HL-60. HYSE induces early apoptosis at $2 \mathrm{ng} / \mathrm{mL}$ after $24 \mathrm{~h}$ treatment of HL-60 cells and the effect is dose-dependent without blockage of the cell cycle. Conversely BTUE and ESE elicited a moderate blockade of the cell cycle at the micromolar level associated with apoptosis. Further research is required to identify chemical components in HYSE, BTUE, and ESE.
\end{abstract}

\section{Introduction}

Marine organisms such as seaweeds, sponges, ascidians, soft corals and other sessile organisms produce a diverse array of novel secondary metabolites [1] with interesting biomedical potential, pharmaceutical relevance and diverse biotechnological applications [2]. The substantially high number of organisms in oceans and consequently the high level of competition between species for survival and space have created the adequate environment for vulnerable sessile organisms to evolve an exquisite chemical-based defence mechanism producing a diverse array of secondary metabolites or natural products [1-3]. Marine natural product research has yielded a considerable number of drug candidates that are in preclinical development and some are on the market [3]. Marine sponges (Phylum: Porifera) as the most primitive type of metazoan are an important source of natural products with anti-inflammatory, hypocholesteromeric, anti-tumour, immunosuppressive, neurosuppressive, muscle relaxants, antiviral, antimalarial, antibiotic and antifouling properties [4,5]. Marine natural products from marine sponges have contributed to nearly $30 \%$ of all marine natural products discovered so far [6] and their chemical diversity constitutes a valuable and unexplored resource for anticancer drug discovery $[3,7]$.

According to the World Health Organization (WHO), cancers figure among the leading causes of morbidity and mortality worldwide. The global cancer burden is estimated to have risen to 18.1 million new cases and 9.6 million deaths in 2018. Cancers of lung, female breast and colorectum are the top three cancer types in terms of incidence and are ranked within the top five in terms of mortality [8]. Moreover, the current range of cytotoxic chemotherapeutic drugs target rapidly dividing cells and therefore affect cancerous cells as well as healthy rapidly dividing cells, causing certain side effects [9]. Thus, there is an urgent need for new anti-cancer therapies, including new cancer drugs with limited side effects, as well as a need to reassess the manner in which cancer is treated.

This present study is a continuation of our effort in finding new bioactive natural products that can act as lead compounds for the development of new treatments for cancer. The cytotoxic properties of 26 sponges (78 extracts) collected from the Mauritius Waters was investigated. Previous studies conducted by the Mauritius Oceanography Institute (MOI) have revealed that marine sponges possess anti-cancer, anti-Alzheimer and anti-diabetic potential [1012]. The potential uncovered within our midst has provided incentive to further investigate species of sponges in Mauritius tropical Waters. Moreover, tropical sessile organisms have been shown to produce a wider array of secondary metabolites, in their fierce competition for survival, than their counterparts of the same species living in more temperate regions [13]. Thus, there is potential of the Mauritian sponges to be sources of natural products with novel structures and anti-cancer properties [14].

${ }^{\star}$ Correspondence to: Avin Ramanjooloo, Mauritius Oceanography Institute, Avenue des Anchois, Morcellement de Chazal, Albion, Mauritius, E-mail aramanjooloo@moi.intnet.mu

Key words: mauritius, marine sponges, cytotoxic, MTT, MTS, apoptosis

Received: April 15, 2020; Accepted: May 06, 2020; Published: May 08, 2020 


\section{Materials and methods}

\section{Materials}

Hexane, ethyl acetate and methanol were purchased from SDFC Limited. DMEM, RPMI-1640, fetal bovine serum, amphotericin B, Trypsin-EDTA and l-glutamine were purchased from PAA Cell Culture. Sodium pyruvate, JC-1, MTT and gentamycin were from Sigma. Paclitaxel was from Enzo Biologicals. CellTiter $96^{\circ}$ Aqueous Non-Radioactive Cell Proliferation Assay (MTS) was from Promega.

\section{Species collection}

Marine sponges involved in this study were collected in the Mauritius Waters through SCUBA diving at depth varying from 5 to $40 \mathrm{~m}$ between 2004 and 2013. Samples were photographed in situ for better species characterization and identification. Voucher samples of each species were identified by Prof. Rob W.M. van Soest and voucher samples were sent at the Zoological Museum of University of Amsterdam, The Netherlands. The species investigated in this study are detailed in Table 1.

\section{Preparation of extracts}

Marine sponges were set free of any debris, cut into small pieces, weighted and freeze dried. The freeze-dried sponge (49-400 g) was macerated with methanol and dichloromethane (1:1) for 24-48 h. After maceration, the solution was filtered and evaporated to dryness on a rotatory vacuum evaporator set at a maximum temperature of 40 ${ }^{\circ} \mathrm{C}$. This constituted the crude extract, which was dissolved in distilled water and partitioned with $n$-hexane followed by ethyl acetate to afford non-polar and semi-polar fractions. The final water extract was freezedried and dissolved in methanol to afford the polar fraction. Inorganic salts were removed from the polar fraction by filtration and redissolving the fraction in methanol. All fractions were stored at $-20{ }^{\circ} \mathrm{C}$ until used. For biological assays, the extracts were dissolved in DMSO to obtain an initial concentration of $10 \mathrm{mg} / \mathrm{mL}$. The final concentration of the extracts and DMSO in the 96 well plate were $50 \mu \mathrm{g} / \mathrm{mL}$ and $0.5 \%$ respectively. This concentration of DMSO did not affect cell viability.

\section{Cell cultures}

Nine human cancer and one human normal cell lines were used for cytotoxicity assays: cervical adenocarcinoma (HeLa), hepatocellular carcinoma (HepG2) and breast adenocarci- noma (MCF7) cell lines were purchased from the American type culture collection (ATCC, Rockville, MD); acute promye- locytic leukemia (HL-60), lung carcinoma (A549), colorectal carcinoma (HCT 116), pancreatic carcinoma (Mia Paca-2), colorectal adenocarcinoma (HCT-15), epidermoid carcinoma (KB) and lung fibroblast (MRC-5) cells were a generous gift from Dr. Thierry Cresteil. HeLa, HL-60, A549, HCT 116, HCT-15 and MCF-7 were cultured in RPMI-1640 while MRC-5, KB, HepG2 and Mia Paca-2 cells were cultured in DMEM, both medium were being supplemented with $10 \%$ (v/v) Foetal Bovine Serum (FBS), $2 \mathrm{mM}$ L-glutamine, amphotericin $\mathrm{B}(10 \mathrm{~mL} / \mathrm{L})$ and $0.1 \%$ gentamycin with the medium for MCF-7 having an additional supplementation of 1 $\mathrm{mM}$ sodium pyruvate. Cells were grown in a humidified incubator with $5 \% \mathrm{CO} 2$ at $37{ }^{\circ} \mathrm{C}$ and upon reaching $80 \%$ confluence were passaged with a solution of $0.25 \%$ trypsin-EDTA.

\section{Cytotoxic screening}

MTT assay: Cytotoxicity was determined as previously described with modifications (Mosmann, 1983). Adherent cells (HeLa, A549, HCT 116, HCT-15, MRC-5, MCF-7, KB, Mia Paca-2 and HepG2) were plated at $1 \times 10^{4}$ cells/well and allowed to incubate for $24 \mathrm{~h}$ at $37^{\circ} \mathrm{C}$. After this incubation period, cells were treated with extracts (hexane, ethyl acetate and methanol) and incubated for $48 \mathrm{~h}$. Control groups received DMSO. After treatment, the old medium was replaced with

Table 1. Description of marine sponges collected from Mauritius Waters

\begin{tabular}{|c|c|c|c|c|}
\hline 1 & Cinachyrella $s p$ & ZAMPOR22176 & Tetillidae & Reddish brown; small, spherical and hard texture with no visible oscules \\
\hline 2 & Pachychalina $s p$ & ZAMPOR22184 & Niphatidae & Reddish white, large size smooth sponge \\
\hline 3 & Echinodictyum pykei & ZAMPOR22180 & Raspailiidae & Dark purple; rough and spiky projection with no visible oscules \\
\hline 4 & Pseudosuberites $s p$ & ZAMPOR22181 & Suberitidae & Dark brown; large and spherical with soft texture \\
\hline 5 & Spirastrella $s p$ & ZAMPOR22175 & Spirastrellidae & Brown; hard texture without definite shape with no visible oscules \\
\hline 6 & Mycale tenuispiculata & ZAMPOR22182 & Mycalidae & Brown; body tinge with reddish surface; large with no visible oscules \\
\hline 7 & Suberites $s p$ & ZAMPOR22179 & Suberitidae & Brown; tinge with blue surface; large and hard texture with no visible oscules \\
\hline 8 & Smenospongia $s p$ & ZAMPOR22199 & Thorectidae & Yellow green; large with visible oscules \\
\hline 9 & Spheciospongia vagabunda & ZAMPOR22174 & Spirastrellidae & Milky green; smooth sponge with large prominent oscules \\
\hline 10 & Myrmekioderma granulatum & ZAMPOR22020 & Halichondriidae & Pale brown; smooth with no visible oscules \\
\hline 11 & Agelas marmarica & ZAMPOR22204 & Agelasidae & Orange; massive and smooth with prominent oscules \\
\hline 12 & Psammoclema sp & ZAMPOR22200 & Phoriospongiidae & Dark brown; small and soft with no visible oscules \\
\hline 13 & Amphimedon $s p$ & ZAMPOR22195 & Niphatidae & Creamy body with reddish surface; large and hard texture with visible oscules \\
\hline 14 & Biemna trirhaphis & ZAMPOR22194 & Desmacellidae & Greenish-brown; soft with no visible oscules \\
\hline 15 & Phyllospongia papyracea* & ZAMPOR22197 & Spongiidae & Brown; flat and large with no visible oscules \\
\hline 16 & Paratetilla $s p$ & ZAMPOR21806 & Tetillidae & Dark brown; hard texture with no visible oscules \\
\hline 17 & Neopetrosia exigua & ZAMPOR21776 & Petrosiidae & Dark brown; smooth and velvety texture with small visible oscules \\
\hline 18 & Hyrtios $s p$ & ZAMPOR21785 & Thorectidae & Brown and purple; rough surface and irregular shape \\
\hline 19 & Gelliodes incrustans & ZAMPOR21804 & Chalinidae & Purple; very soft texture with no visible oscules \\
\hline 20 & Acantella $s p$ & ZAMPOR21794 & Axinellidae & Bright orange; spiky shape and no visible oscules \\
\hline 21 & Cinachyrella australiensis & ZAMPOR21790 & Tetillidae & Creamy brown; smooth with a spherical shape with no visible oscules \\
\hline 22 & Biemna tubulata & ZAMPOR21781 & Desmacellidae & Dark brown; large and soft texture with visible oscules \\
\hline 23 & Epipolasis suluensis & ZAMPOR21800 & Halichondriidae & Creamy brown; large and hard texture with no visible oscules \\
\hline 24 & Neopetrosia tuberosa & ZAMPOR22178 & Petrosiidae & Dark brown; large with visible oscules \\
\hline 25 & Stylissa carteri & ZAMPOR22188 & Dictyonellidae & Reddish brown; hard texture with no visible oscules \\
\hline 26 & Amphimedon navalis pulitzer & ZAMPOR18323 & Niphatidae & Sky blue; smooth with visible oscules \\
\hline
\end{tabular}

*Collected from St. Brandon; Part of Table 1 has been reproduced from supplementary material from Ramanjooloo, et al. 
$200 \mu \mathrm{L}$ of fresh medium, containing MTT $(5 \mathrm{mg} / \mathrm{mL})$ and plates were further incubated for $4 \mathrm{~h}$ at $37^{\circ} \mathrm{C}$. The formazan was dissolved in 100 $\mu \mathrm{L}$ DMSO and the absorbance was measured using a microplate reader at $560 \mathrm{~nm}$ and subtracted at $670 \mathrm{~nm}$. Cytotoxicity was determined using $[\{1-(\mathrm{OD}$ treated/OD control $)\} \times 100]$.

MTS assay and $\mathrm{IC}_{50}$ determination: $\mathrm{KB}$ and HL60 cells were plated in 96-well tissue culture microplates at a density of 650 cells/well in 200 $\mathrm{mL}$ medium and treated $24 \mathrm{~h}$ later with extracts dissolved in DMSO using a Biomek 3000 automation workstation (Beckman-Coulter). Controls received the same volume of DMSO (1\% final volume). After $72 \mathrm{~h}$ exposure MTS reagent (Celltiter 96 Aqueous One solution, Promega) was added and incubated for $3 \mathrm{~h}$ at $37^{\circ} \mathrm{C}$. Absorbance was monitored at $490 \mathrm{~nm}$, subtracted at $670 \mathrm{~nm}$ and results expressed as the inhibition of cell proliferation calculated as the ratio $\left[\left(1-\mathrm{OD}_{490}\right.\right.$ treated $/ \mathrm{OD}_{490}$ control $\left.) \times 100\right]$. For $\mathrm{IC}_{50}$ determinations $(50 \%$ inhibition of cell proliferation) experiments were performed with extracts/ compounds concentrations ranging from $0.1 \mu \mathrm{g} / \mathrm{mL}$ to $0.00001 \mu \mathrm{g} / \mathrm{mL}$.

\section{Cell proliferation assay}

Cells (600 cells/well) were plated in 96-well tissue culture microplates in $200 \mu \mathrm{L}$ of medium and treated $24 \mathrm{~h}$ later with extracts with a concentration range of $0.001-10 \mu \mathrm{g} / \mathrm{mL}$ with a Biomek 3000 automation workstation (Beckman-Coulter). Experiments were performed in duplicate. Control cells received the same volume of DMSO ( $1 \%$ final volume). After $72 \mathrm{~h}$ exposure to the drug, MTS reagent (Promega) was added and incubated for $3 \mathrm{~h}$ at $37^{\circ} \mathrm{C}$. The absorbance was monitored at $490 \mathrm{~nm}$ and results were expressed as the inhibition of cell proliferation calculated as the ratio $\left[\left(1-\left(\mathrm{OD}_{490}\right.\right.\right.$ treated/OD ${ }_{490}$ control) $\times 100]$.

\section{Measurement of Annexin-V-PE/7-AAD staining}

HL-60 cells (5000 cells/well in 96-well microplates) were exposed for $24 \mathrm{~h}$ and $48 \mathrm{~h}$ at $37{ }^{\circ} \mathrm{C}$ under $5 \% \mathrm{CO}_{2}$ with extracts in $100 \mu \mathrm{L}$ complete RPMI-1640 medium. Controls received the same volume of DMSO ( $1 \%$ final volume). $7-\mathrm{AAD}(6.5 \mu \mathrm{L}$ of $1 \mathrm{mg} / \mathrm{mL}$ ethanol solution) and human recombinant annexinV-PE $(6.5 \mu \mathrm{L}$, Bender) were added to $1 \mathrm{~mL}$ binding buffer consisting in $30 \mathrm{mM}$ HEPES buffer, pH7.4, $420 \mathrm{mM} \mathrm{NaCl}$ and $7.5 \mathrm{mM} \mathrm{CaCl}_{2}$ immediately prior to addition to cells. After 20 min incubation at room temperature in the dark, cells were analyzed by flow cytometry with a Guava EasyCyte plus cytometer (Millipore). Cells were classified according to their fluorescence and results expressed as the percentage of cells in each group, calculated on 5000 events.

\section{Cell cycle analysis}

HL-60 cells (25,000 cells/well in 96-well microplates) were exposed for $24 \mathrm{~h}$ and $48 \mathrm{~h}$ at $37^{\circ} \mathrm{C}$ under $5 \% \mathrm{CO}_{2}$ to extract in $100 \mu \mathrm{L}$ complete RPMI-1640 medium. Controls received the same volume of DMSO ( $1 \%$ final volume). Culture media were carefully collected and gently centrifuged to collect floating cells, adherent cells harvested after addition of trypsin, mixed with the pellet of floating cells, washed with PBS and fixed in ice-cold absolute ethanol. After $2 \mathrm{~h}$ at $4{ }^{\circ} \mathrm{C}$, cells were spun down by centrifugation, washed with $2 \%$ FBS in PBS and stained with $50 \mu \mathrm{g} / \mathrm{mL}$ propidium iodide in hypotonic buffer in the presence of RNase A ( $50 \mu \mathrm{g} / \mathrm{mL})$, incubated at dark for $30 \mathrm{~min}$ before being analyzed by flow cytometry with a Guava Easycyte cytometer (Millipore). Cell populations were quantified using Modfit LT (Verity Software House). These experiments were performed at the Institut de Chimie des Substances Naturelle, CNRS. The assays were performed on HL60 cells exposed to HYSE at concentrations of $1 \mathrm{ng} / \mathrm{mL}, 2 \mathrm{ng} /$
$\mathrm{mL}, 5 \mathrm{ng} / \mathrm{mL}$ and BTUE at concentrations of $2 \mathrm{ng} / \mathrm{mL}, 5 \mathrm{ng} / \mathrm{mL}$ and $10 \mathrm{ng} / \mathrm{mL}$. The respective concentrations for HYSE and BTUE were selected, based on the respective $\mathrm{IC}_{50}$ values of each extract on HL60. HL60 cells were exposed to concentrations of each extracts at $24 \mathrm{~h}$ and $48 \mathrm{~h}$. Doxorubicin, at a concentration of $50 \mathrm{~nm}(27.18 \mathrm{ng} / \mathrm{mL})$ was used as control marker (it induced an arrest in G2/M phase).

\section{Statistical Analyses}

The data were subjected to a series of statistical tests performed using the 'statistics and machine learning toolbox' available on the MATLAB R2015 a programming environment. Due to the small size of the dataset investigated, normality tests preluded parametric tests. Normality tests were performed using the Shapiro Wilk's test while homogeneity of variances was checked using Levene's test. The non-normality and inequality of variances in the data revealed from both tests suggested the use of non-parametric inferential statistics. A Kruskal Wallis test was therefore employed as a non-parametric substitute for the one-way ANOVA, followed by a Mann-Whitney $\mathrm{U}$ test as a non-parametric alternative to the unpaired $t$-test. The correlation analysis among the assay methods were performed using the Spearman's correlation test as a non-parametric alternative to the Pearson's correlation test. Box-and-whisker plots were drawn to help with the descriptive statistics of the marine sponge datasets.

\section{Results}

\section{Cytotoxic activity of Mauritian marine sponges}

The cytotoxicity of marine sponges was evaluated in vitro against cancer cell lines: HeLa (cervical cancer); HepG2 (liver cancer); MCF7 (breast cancer); HL-60 (promyelocytic leukemia); A549 (lung cancer); HCT-116 and HCT-15 (colon cancer); PACA (pancreatic cancer) and $\mathrm{KB}$ (oral cancer). A preliminary screening was conducted on three cancer cell lines (HeLa, HL-60 and $\mathrm{KB}$ ) to reveal the relatively more active sponges from a set of 26 , evaluated from hexane, ethyl acetate and methanol extracts at $50 \mu \mathrm{g} / \mathrm{mL}$ by a MTT-based assay (Figure 1). Higher levels of cytotoxicity were observed on average for ethyl acetate extracts (56.7\%) than hexanolic (44.2\%) and methanolic $(33.4 \%)$ extracts.

On average, the highest cytotoxicity on at least two cell lines for hexane extracts were noted for Spirastrella sp (HL-60 $=59 \pm 12 \%$; KB $=75 \pm 2 \% ; \mathrm{HeLa}=80 \pm 2 \%)$ and Amphimedon navalis pulitzer (HL$60=78 \pm 6 \% ; \mathrm{HeLa}=88 \pm 2 \%)$. The cytotoxic activities at the same concentration for ethyl acetate extracts were observed highest on at least two cell lines for Amphimedon navalis pulitzer (HL-60 $=87 \pm 4 \%$; $\mathrm{HeLa}=86 \pm 1 \%)$ and Hyrtios sp (HL-60 = $71 \pm 11 \%$; KB $=94 \pm 1 \%$; $\mathrm{HeLa}=91 \pm 0 \%)$. For methanolic extracts on the other hand, highest cytotoxicity levels were revealed for Amphimedon $s p(\mathrm{~KB}=88 \pm 2 \%$; $\mathrm{HeLa}=90 \pm 0 \%)$ on at least two cell lines.

From a Shapiro Wilk's test conducted (Table 2), the majority of the datasets were revealed not to follow normality at 0.05 level significance at the exception of $\mathrm{KB}$ and HeLa of hexane $(\mathrm{KB}, P=0.193$; HeLa, $P$ $=0.330)$ and methanol $(\mathrm{KB}, P=0.178$; HeLa, $P=0.050)$ extracts. A Levene's test was performed to assess homogeneity of variances. Results showed that the assumption of homoscedasticity was met $(F$ $=1.934, P=0.056)$ and suggested that the groups had equal variances. However, due to the small sample size and non-normality of a number of datasets, non-parametric alternative inferential statistics were used.

A Kruskal Wallis test revealed that the cytotoxicity levels for the three cell lines corresponding to the hexanolic extracts were 


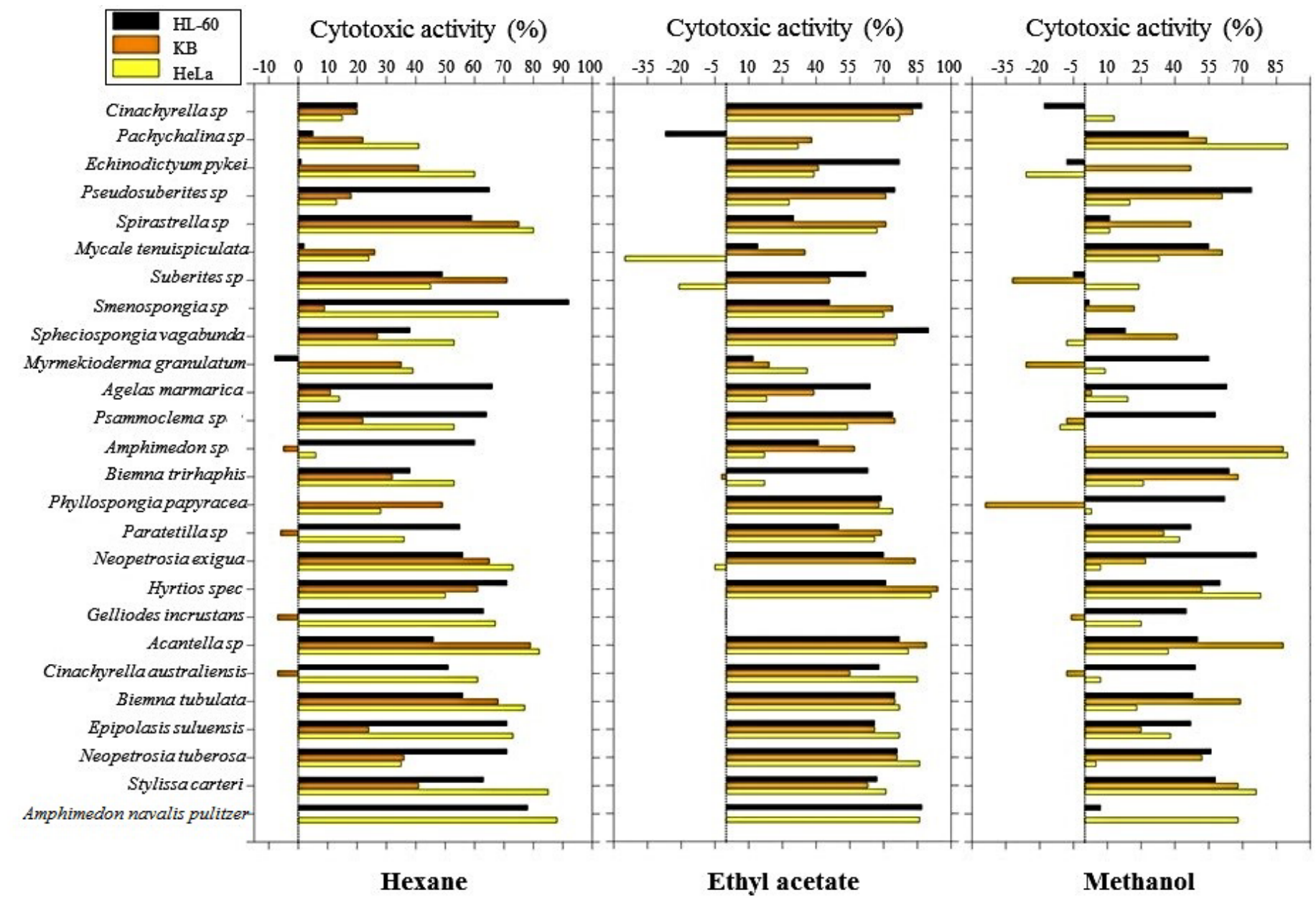

Figure 1. Cytotoxicity levels of hexane, ethyl acetate and methanol extracts of 26 marine sponges tested on 3 cancer cell lines

Table 2. Summary of normality test conducted using the Shapiro Wilk's method. Significance level: $\alpha=0.05$.

\begin{tabular}{|c|c|c|c|c|}
\hline \multirow{2}{*}{ Extracts } & \multirow{2}{*}{ Cell line } & \multicolumn{3}{|c|}{ Shapiro Wilk's test } \\
\cline { 3 - 5 } & & Statistic & df & Significance \\
\hline Hexane & HL-60 & 0.890 & 24 & 0.011 \\
\hline & KB & 0.945 & 24 & 0.193 \\
\hline & HeLa & 0.957 & 25 & 0.330 \\
\hline Ethyl acetate & HL-60 & 0.812 & 24 & $<0.001$ \\
\hline & KB & 0.916 & 23 & 0.048 \\
\hline & HeLa & 0.879 & 24 & 0.009 \\
\hline Methanol & HL-60 & 0.860 & 24 & 0.003 \\
\hline & KB & 0.942 & 23 & 0.178 \\
\hline & HeLa & 0.922 & 25 & 0.050 \\
\hline
\end{tabular}

significantly different $\left(\chi^{2}=6.84, P=0.033\right)$. The same test conducted on the ethyl acetate $\left(\chi^{2}=0.28, P=0.870\right)$ and methanol $\left(\chi^{2}=2.94, P\right.$ $=0.230$ ) extracts showed that no significant difference was reported among the three different cell lines. Pairwise comparison using the Mann Whitney $U$ test confirmed that no significant difference exists among the three cell lines corresponding to the ethyl acetate and methanol extracts. The same test revealed that significant differences exist between HL-60 and KB cell lines $(U=205, P=0.038)$ and between HeLa and KB cell lines $(U=196.5, P=0.016)$ for the hexanolic extracts as observed in the boxplot of Figure 2.

The highest cytotoxic activity was found in the ethyl acetate extracts for all cell lines as confirmed from the relatively higher mean and median of the boxplots (Figure 2). Additionally, the highest activity for the entire dataset was reported for Hyrtios sp (94 $\pm 1 \%$ ) corresponding to the $\mathrm{KB}$ cell line for the ethyl acetate extracts as observed from the high outlier of Figure 2B. The larger spread and interquartile range, representing highly variable cytotoxicity levels are found for the $\mathrm{KB}$ cell line corresponding to the methanolic extracts as observed in Figure 2C. Despite the large spread in cytotoxicity levels observed for the HL60 cell line of the ethyl acetate extracts of Figure 2B, the mid-spread is relatively small and concentrated between the higher $50 \%$ to $75 \%$ distribution.

\section{Identification of the active extracts}

Extracts with anti-proliferative activity higher than $75 \%$ on at least one cancer cell line at $50 \mu \mathrm{g} / \mathrm{mL}$ were regarded as potent enough for further investigation [10]. Figure 3 displays the $75 \%$ cytotoxic threshold level used for the demarcation of the relatively more active extracts. Out of the 26 marine sponges investigated, 18 displayed cytotoxicity levels in at least one of the cell lines and consequently held the promise of being chosen for further screening.

The hexane extracts from 6 sponges which include: Spirastrella $s p$ $(\mathrm{KB}=75 \pm 2 \% ; \mathrm{HeLa}=80 \pm 2 \%)$, Smenospongia spec (HL-60 = $92 \pm 0$ $\%)$, Acantella sp (KB $=(79 \pm 2 \%$; HeLa $=82 \pm 3 \%)$, Biemna tubulata ( $\mathrm{HeLa}=77 \pm 3 \%)$, Stylissa carteri $(\mathrm{HeLa}=85 \pm 1 \%)$, and Amphimedon navalis pultzer $(\mathrm{HL}-60=78 \pm 6 \%$; $\mathrm{HeLa}=88 \pm 2 \%)$ revealed cytotoxic activity $\geq 75 \%$ in at least one of the three cell lines. For the ethyl acetate 

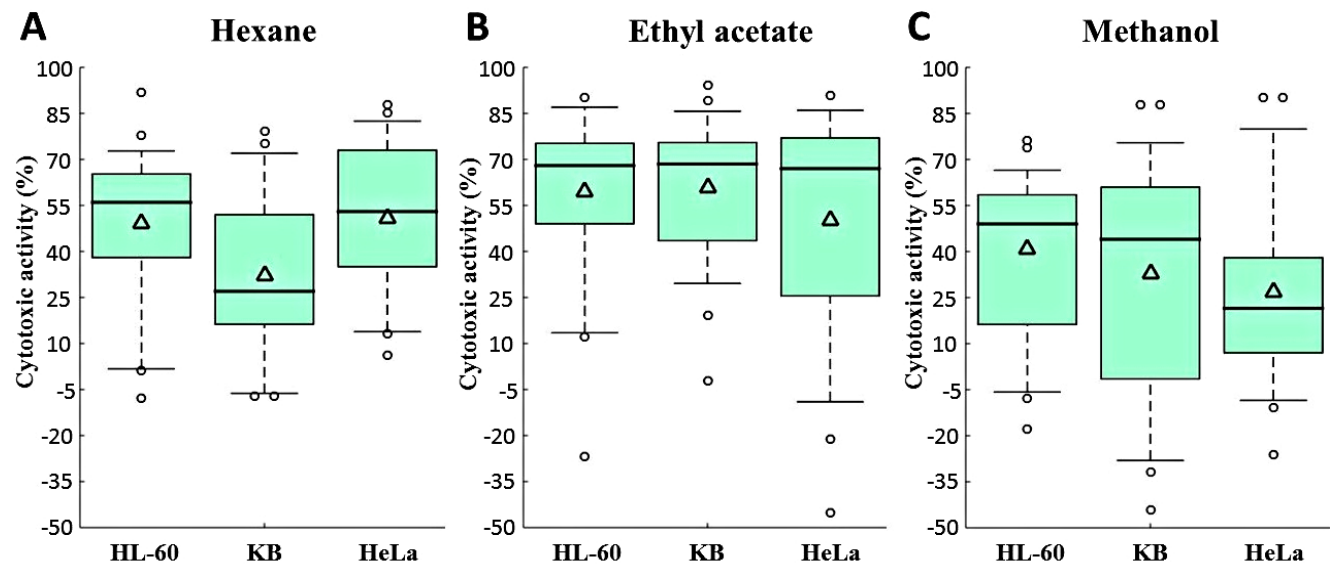

Figure 2. Box plots showing variation in cytotoxic activity (\%) for (A) hexane, (B) ethyl acetate and (C) methanol extracts corresponding to the 3 cell lines. $\Delta$ : Mean of the distribution

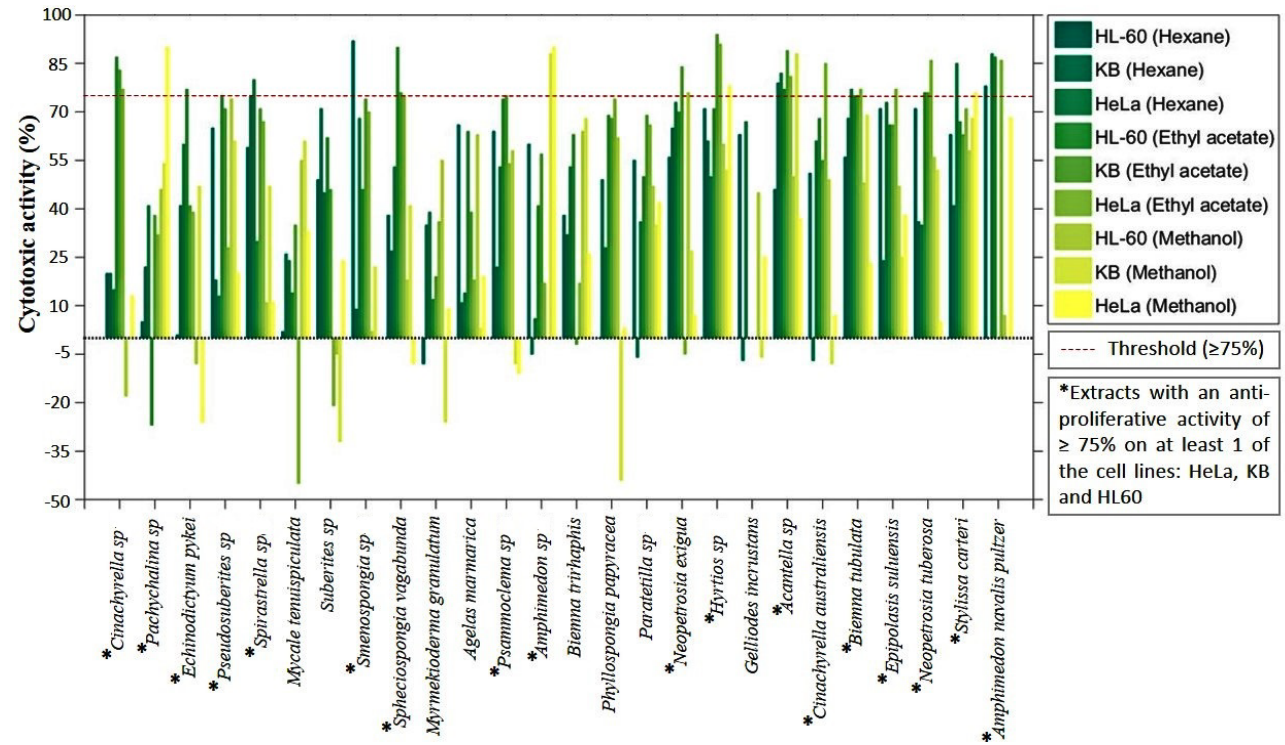

Figure 3. Cytotoxic activity of all extracts corresponding to the 3 cell lines (HeLa, KB and HL-60) investigated. Threshold line of $75 \%$ displayed on the diagram. Extracts were regarded as potent whenever at least 1 cell lines exceeded this threshold

extracts, 14 sponges which include: Cinachyrella sp (HL-60 $=87 \pm 1 \%$; $\mathrm{KB}=83 \pm 1 \% ; \mathrm{HeLa}=77 \pm 1 \%)$, Echinodictyum pykei $(\mathrm{HL}-60=77 \pm$ $1 \%$ ), Pseudosuberites sp (HL-60 $=75 \pm 1 \%$ ), Spheciospongia vagabunda (HL-60 = $90 \pm 1 \% ; \mathrm{KB}=76 \pm 2 \%$; HeLa $=75 \pm 4 \%)$, Psammoclema $s p$ $(\mathrm{KB}=75 \pm 4 \%)$, Neopetrosia exigua $(\mathrm{KB}=84 \pm 4 \%)$, Hyrtios sp $(\mathrm{KB}$ $=94 \pm 1 \%$; HeLa $=91 \pm 0 \%)$, Acantella $s p$ (HL-60 = $77 \pm 0 \%$; KB = $89 \pm 4 \% ; \mathrm{HeLa}=81 \pm 1 \%)$, Cinachyrella australiensis $(\mathrm{HeLa}=85 \pm 1$ $\%$ ), Biemna tubulata (HL-60 = $75 \pm 3 \%$; KB = $75 \pm 11 \%$; HeLa = 77 $\pm 3 \%$ ), Epipolasis suluensis ( HeLa $=77 \pm 1 \%$ ), Neopetrosia tuberosa (HL-60 $=76 \pm 7 \% ; \mathrm{KB}=76 \pm 7 \%$; HeLa $=86 \pm 0 \%)$ and Amphimedon navalis pultzer (HL-60 $=87 \pm 4 \%$; HeLa $=86 \pm 1 \%$ ) displayed activity $\geq 75 \%$ in at least one of the three cell lines. The methanol extracts on the other hand showed cytotoxic activity $\geq 75 \%$ in at least one of the three cell lines for five sponges which include: Pachychalina sp $(\mathrm{HeLa}=$ $90 \pm 0 \%)$, Amphimedon sp (KB= $88 \pm 2 \%$; HeLa = $90 \pm 0 \%)$, Hyrtios $s p(\mathrm{HeLa}=78 \pm 9 \%)$, Acantella $s p(\mathrm{~KB}=88 \pm 2 \%)$ and Stylissa carteri $(\mathrm{HeLa}=76 \pm 2 \%)$.

According to available literature, non-polar extracts are known to have relatively lower anti-cancer activity levels compared to semipolar and polar compounds $[15,16]$. However, cases where non-polar fractions were found to exert higher growth inhibitory activity than semi-polar and polar compounds on several cancer cell lines have been reported [17]. Consequently, out of the 18 sponges identified having $\geq 75 \%$ on at least one cell line, emphasis was placed on 9 sponges corresponding to 10 extracts, primarily focusing on the ethyl acetate extracts. Two of the extracts were chosen corresponding to their relatively good cytotoxic activity level for the hexanolic extracts. The extracts chosen include: CSE, NETE, BTUE, HYSE, SVE, SPSH, ESH, ESE, PSME and NEE and were further screened at $50 \mu \mathrm{g} / \mathrm{mL}$ on HCT15, HCT116, HepG2, A549, PACA and MFC7 human cancer cell lines and also on the human non-cancer cell line MRC5.

\section{Further screening of active extracts}

The cytotoxic activities of the 10 selected extracts were further screened at $50 \mu \mathrm{g} / \mathrm{mL}$ on an additional 6 cancer cell lines and a noncancer cell line as illustrated in Figure 4A. From Shapiro Wilk's test (Table 3), it was revealed that with the exception of Neopetrosia tuberosa $(P=0.010)$, Biemna tubulata $(P=0.025)$ and Hyrtios sp $(P=$ $0.022)$ for the ethyl acetate extracts in addition to Epipolasis suluensis $(P=0.034)$ for the hexanolic extracts, most of the datasets satisfied the normality tests at 0.05 level significance. From Levene's test for equality of variances, it was revealed that the associated probability for the $F$ test 

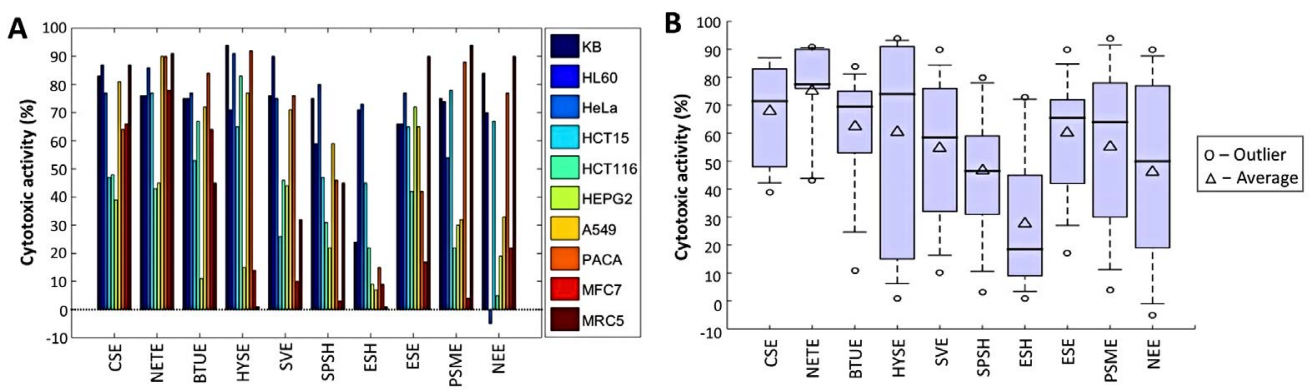

Figure 4. (A) Cytotoxic activities of 10 selected extracts screened at $50 \mu \mathrm{g} / \mathrm{mL}$ on 10 cell lines. (B) Boxplot representing the distribution of cytotoxic levels from each extract selected

Table 3. Summary of normality test conducted using the Shapiro Wilk's method. Significance level: $\alpha=0.05$.

\begin{tabular}{|c|c|c|c|c|c|}
\hline \multirow{2}{*}{ Extracts } & \multirow{2}{*}{ Sponge specimen } & \multirow{2}{*}{ Code } & \multicolumn{3}{|c|}{ Shapiro Wilk's test } \\
\cline { 4 - 6 } & & & Statistic & df & Significance \\
\hline Ethyl acetate & Cinachyrella $s p$ & CSE & 0.888 & 9 & 0.160 \\
\hline & Neopetrosia tuberosa & NETE & 0.786 & 9 & 0.010 \\
\hline & Biemna tubulata & BTUE & 0.816 & 9 & 0.025 \\
\hline & Hyrtios $s p$ & HYSE & 0.815 & 9 & 0.022 \\
\hline & Spheciospongia vagabunda & SVE & 0.923 & 9 & 0.379 \\
\hline & Epipolasis suluensis & ESE & 0.911 & 9 & 0.286 \\
\hline & Psammoclema $s p$ & PSME & 0.920 & 9 & 0.360 \\
\hline & Neopetrosia exigua & NEE & 0.903 & 9 & 0.237 \\
\hline Hexane & Spirastrella $s p$ & SPSH & 0.966 & 9 & 0.851 \\
\hline & Epipolasis suluensis & ESH & 0.831 & 9 & 0.034 \\
\hline
\end{tabular}

was smaller than 0.05 , rejecting the assumption of homoscedasticity. Consequently, non-parametric alternative inferential statistics were employed.

From the Kruskal Wallis test, it was revealed that the cytotoxic activities corresponding to the 10 different extracts were significantly different from each other $\left(\chi^{2}=19.64, P=0.020\right)$. The main distributions of the individual extracts can be observed from the boxplot of Figure 4B. The inherently higher mean $(75.2 \%)$ and median $(75.4 \%)$ cytotoxicity levels of the ethyl acetate extracts of Neopetrosia tuberosa corresponding to the combined effects of all 10 cell lines were reported. However, despite showing cytotoxic activity of $\geq 75 \%$ on 7 cancer cell lines (KB, HL-60, HeLa, HCT15, A549, MFC7 and PACA), the extract displayed one of the highest cytotoxic activity on the MRC5 non-cancer cell line (91\%), as illustrated in the radar plot of Figure 5B.

As observed from the radar plot of Figure 5D the ethyl acetate extract of Hyrtios sp displayed cytotoxic activity of $\geq 75 \%$ on 5 cancer cell lines (KB, HeLa, HCT116, A549 and PACA) while maintaining low activity on the MRC5 non-cancer cell line (1\%). Similarly, the ethyl acetate extract of Spheciospongia vagabunda reported cytotoxic activity of $\geq 75 \%$ on 4 cancer cell lines (KB, HL- 60 , HeLa and PACA) while exhibiting low activity on the MRC non-cancer cell line (32\%). Due to the low activity reported on the MRC5 non-cancer cell line while showing high cytotoxic activity on cancer cell lines, the two abovementioned ethyl acetate extracts namely Hyrtios sp and Spheciospongia vagabunda have the potential of being used in the pharmaceutical industry as anti-cancer remedies.

The average cytotoxic activity on the 9 cancer cell lines for the ethyl acetate extract of Hyrtios sp and Spheciospongia vagabunda are $66.9 \%$ and $57.1 \%$ respectively. The HYSE extract displays the largest spread and interquartile range among the cytotoxic levels of all extracts chosen for further investigation. On average, higher cytotoxic activity was reported on HL-60 (73.9\%) followed by KB (72.8\%) cell lines for all
10 extracts. This indicates that the extracts chosen for further screening were more effective against HL-60 promyelocytic leukemia and KB oral cancer. The lowest activity was reported on MFC7 (28.7\%) and HepG2 (30.6\%) cell lines for all 10 extracts, which implied, the sponges selected were less effective against breast and liver cancers respectively.

\section{Correlation between cancer and non-cancer cell lines}

With the objective to rationalize the degree to which the cancer and non-cancer cell lines are associated, a correlation analysis was conducted. The Spearman correlation coefficients were derived and the pairwise comparison was performed between each cancer cell line and the MRC5 non-cancer cell line (Figure 6). No significant correlations were observed between KB and MRC5 ( $\rho=-0.019, P=0.959)$; HL 60 and MRC5 ( $\rho=0.006, P=0.987)$; A549 and MRC5 ( $\rho=0.031, P=$ $0.933)$. Negative linear correlations were observed between HeLa and MRC5 $(\rho=-0.229)$ in addition to that between HCT116 and MRC5 ( $\rho$ $=-0.396$ ). It gives an indication of the relatively opposing mechanisms taking place in the two different cell lines. For all extracts considered, as the cytotoxic activity of the non-cancer cell decreased, a low to fair increase was observed in the HeLa and HCT116 cell lines, respectively. Low to strong positive linear correlations were found for the remaining 4 pairwise comparisons (HCT15, HepG2, PACA and MFC7). The highest positive linear correlations were observed between HCT15 and MRC5 $(\rho=0.766)$ followed by HepG2 and MRC5 $(\rho=0.575)$. Consequently, the mechanism of action in the HCT15 and HepG2 cancer cell lines was in accordance with that of the non-cancer cell line. This indicates that for all extracts considered, as the cytotoxic activity of the two cancer cell lines increases, an accompanied good to strong increase was also registered in the non-cancer cell line.

\section{Testing selected extracts by MTS assay}

The same 10 extracts were further tested at $10 \mu \mathrm{g} / \mathrm{mL}$ and $1 \mu \mathrm{g} / \mathrm{mL}$ for the KB cell line by MTS assay. Four extracts HYSE, BTUE, NETE and ESE were tested for their cytotoxic activity at $1010 \mu \mathrm{g} / \mathrm{mL}$ and 1 $\mu \mathrm{g} / \mathrm{mL}$ on KB cells. BTUE showed activity of $99 \pm 1 \%$ at $10 \mu \mathrm{g} / \mathrm{mL}$ and $86 \pm \%$ at $1 \mu \mathrm{g} / \mathrm{mL}$; HYSE showed activity of $100 \pm 1 \%$ at $10 \mu \mathrm{g} / \mathrm{mL}$ and $98 \pm 2 \%$ at $1 \mu \mathrm{g} / \mathrm{mL}$; NETE showed activity of $97 \pm 1 \%$ at $10 \mu \mathrm{g} / \mathrm{mL}$ and no activity at $1 \mu \mathrm{g} / \mathrm{mL}$; and ESE showed activity of $99 \pm 1 \%$ at $10 \mu \mathrm{g} /$ $\mathrm{mL}$ and $97 \pm \%$ at $1 \mu \mathrm{g} / \mathrm{mL}$. Since the extracts BTUE, HYSE and ESE maintained their high activity on $\mathrm{KB}$ cells at $1 \mu \mathrm{g} / \mathrm{mL}$, their $\mathrm{IC}_{50}$ were performed on KB cells as well as HL60 cells by MTS assay. Conversely, NETE had relatively high cytotoxic activity on $\mathrm{KB}$ cells at $10 \mu \mathrm{g} / \mathrm{ml}$ but did not maintain cytotoxicity at $1 \mu \mathrm{g} / \mathrm{mL}$. The $\mathrm{IC}_{50}$ values of BTUE, ESE and HYSE on KB cells were $0.48 \mu \mathrm{g} / \mathrm{mL}, 85 \mathrm{ng} / \mathrm{mL}$ and $0.5 \mathrm{ng} / \mathrm{mL}$ respectively. On HL-60 cells the IC $_{50}$ values of BTUE, ESE and HYSE were $1.44 \mu \mathrm{g} / \mathrm{mL}, 2.28 \mu \mathrm{g} / \mathrm{mL}$ and $1.3 \mathrm{ng} / \mathrm{mL}$ respectively. Among the three extracts, HYSE was more active that BTUE and ESE as it displayed $\mathrm{IC}_{50}$ values at nano-level concentrations on both cell lines. 

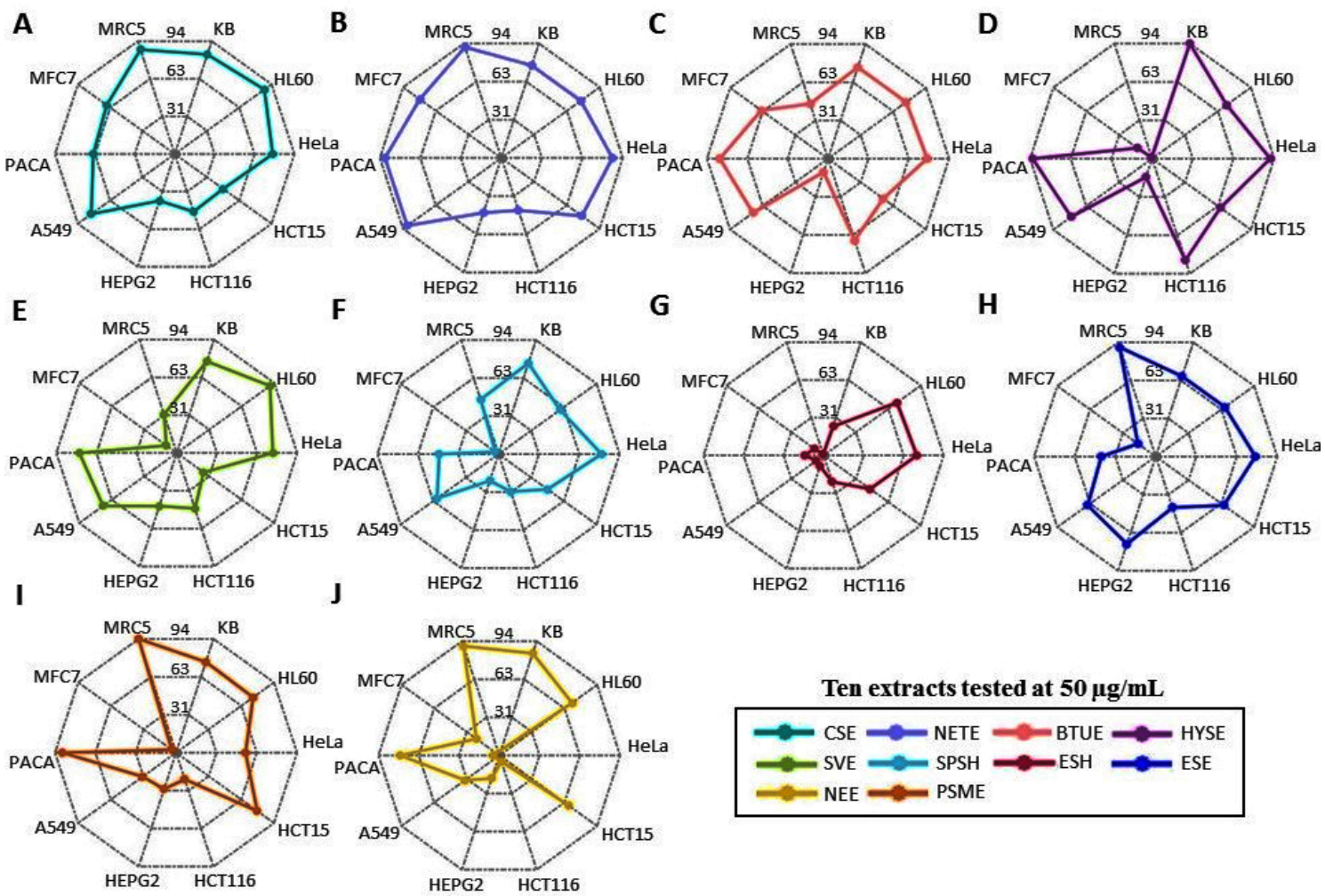

HEPG2 HCT116

HEPG2 HCT116

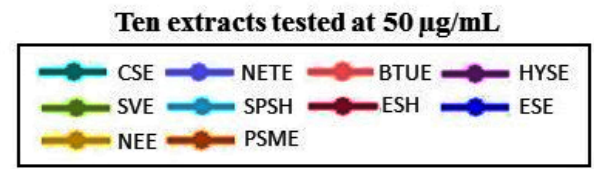

Figure 5. Radar chart displaying the multivariate cytotoxic data from all 10 cell lines simultaneously for (A) CSE (B) NETE (C) BTUE (D) HYSE (E) SVE (F) SPSH (G) ESH (H) ESE (I) PSME (J) NEE extracts

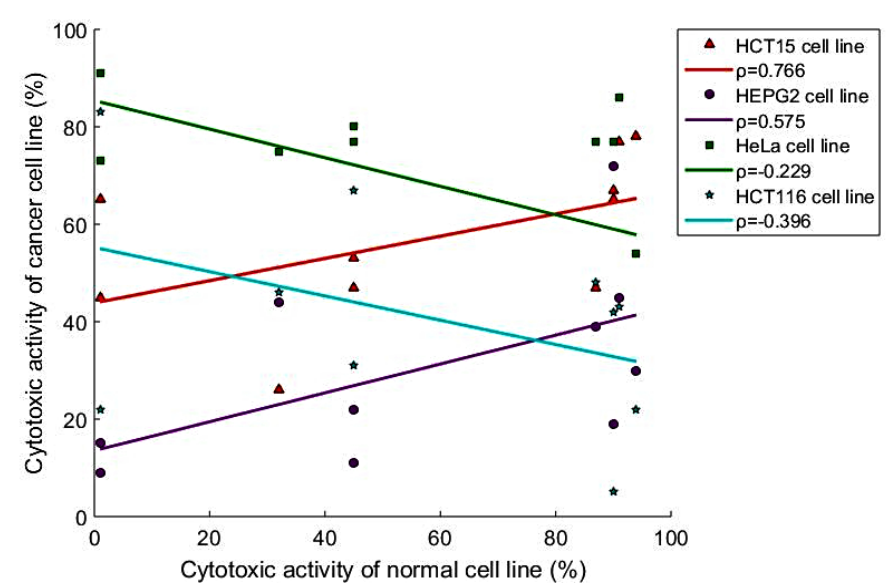

Figure 6. Linear regression plots and Spearman's correlation coefficients of HCT15, HepG2, HeLa and HCT116 cancer cell lines against the MRC5 non-cancer cell line

\section{Cell cycle by FACS (Fluorescence-Activated Cell Sorting) on HL-60 cells.}

To investigate the mechanism of inhibitory effect of BTUE, ESE and HYSE extracts on HL-60 cell proliferation, cell cycle distribution was evaluated using flow cytometry. Table 4 shows the percentage of cells in each phase in control (1\% DMSO) and treated cells at $24 \mathrm{~h}$ and $48 \mathrm{~h}$. The sub-G1 population indicated apoptotic-associated chromatin degradation. Doxorubicin was used as control marker (it induced an arrest in G2/M phase). HYSE at concentrations ranged 1 to $5 \mathrm{ng} / \mathrm{mL}$ did not induce a blockade of the cell cycle. However, BTUE induced mild cell arrest of HL60 at $10 \mu \mathrm{g} / \mathrm{ml}$, after $24 \mathrm{~h}$ exposure, during both the
G2/M and SubG1 phases. No cell arrest was detected at $48 \mathrm{~h}$ exposure as the cells had already undergone apoptosis. For ESE, a moderate blockade, at high doses, was detected in the G2/M phase.

The ability of BTUE to induce cell arrest at both the G2/M and SubG1 phases could be an indication of its potential as an agent which modulates cell cycle check points [18]. Modulators of cell cycle check points have become an important class of drugs, due to their ability to stop cell cycle progression and induce apoptotis [18]. Thus, BTUE could be causing DNA damage which forces the cells into arrest and induce apoptosis, or BTUE could be acting on promoters of cell cycle progression such as cyclins or CDKs

\section{Apoptosis analysis by FACS}

To further examine the involvement of cell apoptosis in cytotoxicity, HL-60 cells were stained with annexin V-7-AAD and subsequently analyzed by flow cytometry. This assay is based in the translocation of phosphotidylserine from the inner leaflet of the plasma membrane to the cell surface in the early apoptotic cells. Cells were treated with extracts for 24 and $48 \mathrm{~h}$. As shown in Table 5, a marked increase in the apoptotic pathway was noticeable in HL-60 cells at concentration as low as $2 \mathrm{ng} / \mathrm{mL}$ HYSE. Furthermore, the effect was shown to be doseand time-dependent.

Then the BTUE and ESE extracts were evaluated with higher concentrations than the concentrations used for HYSE. In line with the $\mathrm{IC}_{50}$ measured on HL-60, cells enter early apoptosis and to a smaller extent in late apoptosis in a dose-and time-dependent manner.

\section{Discussion}

Based on preliminary screening and interpreting these results together, we selected eight ethyl acetate extracts namely CSE, 
Table 4. Cell cycle analysis of HL-60 cells

\begin{tabular}{|c|c|c|c|c|c|}
\hline & & $\mathrm{G} 2 / \mathrm{M}$ & S-Phase & $\mathrm{G} 0 / \mathrm{G} 1$ & SubG1 \\
\hline \multirow{14}{*}{$24 \mathrm{~h}$} & Untreated & 7.4 & 51.3 & 39.3 & 2.0 \\
\hline & DMSO & 7.6 & 49.8 & 40.2 & 2.4 \\
\hline & Doxo $50 \mathrm{nM}$ & 57.0 & 33.8 & 6.6 & 2.6 \\
\hline & HYSE $1 \mathrm{ng} / \mathrm{mL}$ & 8.6 & 42.2 & 45.1 & 4.1 \\
\hline & HYSE $2 \mathrm{ng} / \mathrm{mL}$ & 9.5 & 42.0 & 41.9 & 6.6 \\
\hline & HYSE $5 \mathrm{ng} / \mathrm{mL}$ & 6.5 & 38.9 & 48.6 & 6.0 \\
\hline & Untreated & 8.6 & 47.1 & 42.4 & 1.9 \\
\hline & Dmso & 7.5 & 48.9 & 41.4 & 2.2 \\
\hline & BTUE $2 \mu \mathrm{g} / \mathrm{ml}$ & 11.4 & 39.3 & 44.6 & 4.7 \\
\hline & BTUE $5 \mu \mathrm{g} / \mathrm{ml}$ & 12.7 & 42.6 & 37.0 & 7.7 \\
\hline & BTUE $10 \mu \mathrm{g} / \mathrm{ml}$ & 23.6 & 57.4 & 14.8 & 4.2 \\
\hline & ESE $5 \mu \mathrm{g} / \mathrm{ml}$ & 12.1 & 37.9 & 46.5 & 3.5 \\
\hline & ESE $10 \mu \mathrm{g} / \mathrm{ml}$ & 14.2 & 37.4 & 44.9 & 3.5 \\
\hline & ESE $20 \mu \mathrm{g} / \mathrm{ml}$ & 17.3 & 42.8 & 32.2 & 7.7 \\
\hline \multirow{14}{*}{$48 \mathrm{~h}$} & Untreated & 4.0 & 51.3 & 42.5 & 2.2 \\
\hline & DMSO & 5.9 & 49.9 & 42.9 & 1.3 \\
\hline & Doxo $50 \mathrm{nM}$ & 72.0 & 12.8 & 9.1 & 6.1 \\
\hline & HYSE $1 \mathrm{ng} / \mathrm{ml}$ & 9.2 & 31.4 & 58.0 & 1.4 \\
\hline & HYSE $2 \mathrm{ng} / \mathrm{ml}$ & 7.5 & 31.2 & 59.6 & 1.7 \\
\hline & HYSE $1 \mathrm{ng} / \mathrm{ml}$ & 9.6 & 32.5 & 55.2 & 2.7 \\
\hline & Untreated & 7.1 & 47.2 & 44.6 & 1.0 \\
\hline & DMSO & 9.8 & 46.8 & 42.5 & 1.0 \\
\hline & BTUE $2 \mu \mathrm{g} / \mathrm{ml}$ & 10.3 & 41.7 & 43.7 & 4.3 \\
\hline & BTUE $5 \mu \mathrm{g} / \mathrm{ml}$ & 10.0 & 41.3 & 43.4 & 5.3 \\
\hline & BTUE $10 \mu \mathrm{g} / \mathrm{ml}$ & 9.5 & 45.5 & 23.8 & 21.2 \\
\hline & ESE $5 \mu \mathrm{g} / \mathrm{ml}$ & 10.3 & 45.2 & 42.0 & 2.5 \\
\hline & ESE $10 \mu \mathrm{g} / \mathrm{ml}$ & 7.0 & 47.3 & 42.3 & 3.4 \\
\hline & ESE $20 \mu \mathrm{g} / \mathrm{ml}$ & 8.4 & 48.0 & 38.7 & 4.8 \\
\hline
\end{tabular}

Table 5. Measurement of Annexin-V-PE/7-AAD staining

\begin{tabular}{|c|c|c|c|c|c|}
\hline & & Necrotic & $\begin{array}{c}\text { late } \\
\text { apoptosis }\end{array}$ & Intact & $\begin{array}{c}\text { early } \\
\text { apoptosis }\end{array}$ \\
\hline \multirow{14}{*}{$24 \mathrm{~h}$} & Untreated & 0.1 & 0.2 & 91.7 & 8.0 \\
\hline & DMSO & 0.1 & 0.2 & 91 & 8.7 \\
\hline & doxo $50 \mathrm{nM}$ & 0.1 & 0.3 & 73.9 & 25.7 \\
\hline & HYSE $1 \mathrm{ng}$ & 0 & 0.2 & 90.0 & 9.8 \\
\hline & HYSE 2 ng & 0.1 & 0.1 & 87.3 & 12.5 \\
\hline & HYSE $10 \mathrm{ng}$ & 0.1 & 0.1 & 83.9 & 15.9 \\
\hline & Untreated & 1.0 & 1.6 & 90.9 & 6.5 \\
\hline & doxo $50 \mathrm{nM}$ & 0.6 & 3.9 & 82.5 & 13 \\
\hline & BTUE $2 \mu \mathrm{g}$ & 0.5 & 4 & 72.1 & 23.4 \\
\hline & BTUE $5 \mu \mathrm{g}$ & 0.6 & 6.9 & 56.3 & 36.2 \\
\hline & BTUE $10 \mu \mathrm{g}$ & 3 & 10.9 & 51.2 & 34.9 \\
\hline & ESE $5 \mu \mathrm{g}$ & 0.5 & 3.9 & 73.2 & 22.4 \\
\hline & ESE $10 \mu \mathrm{g}$ & 0.4 & 4.8 & 68.7 & 26.1 \\
\hline & ESE $20 \mu \mathrm{g}$ & 0.4 & 7.1 & 58.8 & 33.7 \\
\hline \multirow{14}{*}{$48 \mathrm{~h}$} & Untreated & 0.1 & 0.1 & 92.0 & 7.8 \\
\hline & DMSO & 0.1 & 0.1 & 86.6 & 13.2 \\
\hline & doxo $50 \mathrm{nM}$ & 0.1 & 1.7 & 14.0 & 84.2 \\
\hline & HYSE $1 \mathrm{ng}$ & 0.1 & 0.2 & 82.9 & 16.8 \\
\hline & HYSE 2 ng & 0.1 & 0.1 & 72.7 & 27.1 \\
\hline & HYSE $10 \mathrm{ng}$ & 0 & 0.3 & 52.3 & 47.4 \\
\hline & Untreated & 0.8 & 1.5 & 89.7 & 8.0 \\
\hline & doxo $50 \mathrm{nM}$ & 0.3 & 5.2 & 64.8 & 29.7 \\
\hline & BTUE $2 \mu \mathrm{g}$ & 0.3 & 7.5 & 42.4 & 49.8 \\
\hline & BTUE $5 \mu \mathrm{g}$ & 0.4 & 13.1 & 15.7 & 70.8 \\
\hline & BTUE $10 \mu \mathrm{g}$ & 1.9 & 25.4 & 15.9 & 56.7 \\
\hline & ESE $5 \mu \mathrm{g}$ & 0.6 & 7.7 & 53.1 & 38.6 \\
\hline & ESE $10 \mu \mathrm{g}$ & 0.2 & 9.0 & 38.8 & 52.0 \\
\hline & ESE $20 \mu \mathrm{g}$ & 0.3 & 27.7 & 10.6 & 61.4 \\
\hline
\end{tabular}

NETE, NEE, SVE, PMSE, BTUE, HYSE, ESE obtained from sponges Cinachyrella sp, Neopetrosia tuberosa, Neopetrosia exigua, Spheciospongia vagabunda, Psammoclema sp, Biemna tubulata, Hyrtios sp, and Epipolasis suluensis respectively for discussions putting more emphasis on BTUE, HYSE and ESE.

i) Cinachyrella sp: We reported the ethyl acetate extract (CSE) of this sponge to have cytotoxic activity greater than $75 \%$ on $\mathrm{KB}, \mathrm{HL}-60$, HeLa, A549 cell lines when evaluated at $50 \mu \mathrm{g} / \mathrm{mL}$ by MTT assay. Additionally, this same extract displayed an activity of $96 \%$ on KB cells at $10 \mu \mathrm{g} / \mathrm{mL}$ but only $2 \%$ activity at $1 \mu \mathrm{g} / \mathrm{mL}$ by MTS assay. Nurhayati, et al. [19] reported an $\mathrm{IC}_{50}$ value of $897,809 \mu \mathrm{g} / \mathrm{mL}$ of the ethanolic extract of the sponge Cinachyrella $s p$ on HeLa cell line. Machida, et al. [20] reported the isolation of Cinanthrenol A, a new steroid composed of a phenanthrene and a spiro $[2,4]$ heptane system and was the first phenathrene-containing steroid with estrogen activity from this sponge.

ii) Neopetrosia tuberosa: The ethyl acetate extract (NETE) of this sponge displayed an activity of greater than $75 \%$ on six cancer cell lines (KB, HL-60, HeLa, HCT15, A549 and PACA) and 91\% on MRC5 at $50 \mu \mathrm{g} / \mathrm{mL}$ when evaluated by MTT assay. Moreover, by MTS assay this extract displayed $97 \pm 1 \%$ activity on KB cells at $10 \mu \mathrm{g} / \mathrm{mL}$ but no activity at $1 \mu \mathrm{g} / \mathrm{mL}$. Literature search showed that the cytotoxic activity of the extract from this species has not been reported. The chemical and bioactive diversities of marine sponge of the genus Neopetrosia have been reviewed by Qaralleh [20]. This genus was found to have biological activities such as anti-microbial, anti-fouling, anti-HIV, cytotoxic, anti-tumor, antiproliferation, anti-angiogenic and anti-invasion activities. More than 85 compounds were isolated from Neopetrosia species and were classified into alkaloids, quinones, sterols and terpenoids [21].

iii) Neopetrosia exigua: The ethyl acetate extract (NEE) of the sponge Neopetrosia exigua showed a cytotoxic activity greater or equal to $70 \%$ on KB, HL- 60 , MFC7 and $90 \%$ on MRC5 at $50 \mu \mathrm{g} / \mathrm{mL}$ by MTT assay and $99 \%$ activity on $\mathrm{KB}$ cells at $10 \mu \mathrm{g} / \mathrm{mL}$ but $52 \%$ activity at $1 \mu \mathrm{g} / \mathrm{mL}$ by MTS assay. This sponge has received great attention in natural product chemistry due to its novel bioactive metabolites showing bioactivities such as vasodilation, cytotoxicity and antibacterial [22].

iv) Spheciospongia vagabunda: The ethyl acetate extract (SVE) of this sponge from Mauritian Waters showed cytotoxicity greater than $70 \%$ against KB, HL-60, HeLa, A549 and PACA, and 32\% on MRC5 at $50 \mu \mathrm{g} / \mathrm{mL}$ when evaluated by MTT assay. Additionally, this extract displayed an activity of $93 \%$ activity on KB cells at $10 \mu \mathrm{g} / \mathrm{mL}$ but no activity at $1 \mu \mathrm{g} / \mathrm{mL}$. SVE showed a relatively low cytotoxicity on MRC5 compared to its cytotoxicity on cancer cell lines. Eltamany, et al. [23] also conducted studies on Spheciospongia vagabunda from the Red Sea. Its extract displayed potential anti-tumor activity against HepG2 and MCF-7 with $\mathrm{IC}_{50}$ value of $28.1 \mu \mathrm{g} / \mathrm{mL}$ and $19.7 \mu \mathrm{g} / \mathrm{mL}$ respectively. They isolated three new ceramides which had cytotoxic activity against HepG2, MFC7 and HFB4 (normal melanocytes). In comparison to the data by Eltamany, et al. [23], our extract when tested at $50 \mu \mathrm{g} / \mathrm{mL}$ had relatively low cytotoxicity of $44 \%$ and $10 \%$ on HepG2 and MFC7 respectively by MTT assay. This difference could be due to the number of cells used per well for cytotoxic activity. In this study, 10,000 cells per well were used whereas Eltamany, et al. [23] used 104 cells per well. 
v) Psammoclema sp: We reported the cytotoxicity activity greater than $75 \%$ of the ethyl acetate extract from this sponge against $\mathrm{KB}$, HL-60, HCT15, and PACA and $94 \%$ on MRC5 at $50 \mu \mathrm{g} / \mathrm{mL}$ by MTT assay. And an activity of $56 \%$ on $\mathrm{KB}$ cells at $10 \mu \mathrm{g} / \mathrm{mL}$ but no activity at $1 \mu \mathrm{g} / \mathrm{mL}$ when evaluated by MTS assay. Chevallier, et al. [24] reported the high activity of the crude extract of Psammoclemma $s p$. on $\mathrm{KB}$ cells and the isolation of the two macrolides chondropsin A and 73-deoxychondropsin A. These compounds were evaluated for their cytotoxic activity towards several tumor cell lines and exhibited an $\mathrm{IC}_{50}$ of approximately $10^{-10} \mathrm{M}$. Furthermore, Holland, et al. [25] isolated four new trihydroxysterols (1-4) which inhibited the growth of colorectal, breast, ovarian, and prostate cancer cell lines $\left(\mathrm{GI}_{50} 5-27 \mu \mathrm{M}\right)$ and OJika, et al. [26] isolated unique polyene amides namely Clathrynamide $\mathrm{A}$ and three new derivatives from the sponge Psammoclema $s p$ which displayed anti-fungal activity.

vi) Hyrtios sp: The ethyl acetate extract (HYSE) of the sponge Hyrtios sp. showed cytotoxicity greater than $70 \%$ against five cancer cell lines namely HL-60, HeLa, HCT116, A549 and PACA at $50 \mu \mathrm{g} /$ mL by MTT assay. Additionally, MTS assay showed that HYSE displayed cytotoxic activity of $100 \pm 1 \%$ and at $98 \pm 2 \%$ at 10 $\mu \mathrm{g} / \mathrm{mL}$ and $1 \mu \mathrm{g} / \mathrm{mL}$ on $\mathrm{KB}$ respectively. The $\mathrm{IC}_{50}$ values of HYSE on $\mathrm{KB}$ and $\mathrm{HL}-60$ were $0.5 \mathrm{ng} / \mathrm{mL}$ and $1.3 \mathrm{ng} / \mathrm{mL}$ respectively. Cell cycle analysis by FACS conducted on HL-60 cells exposed to HYSE for 24 and $48 \mathrm{~h}$ showed that HYSE at concentrations ranging from 1 to $5 \mathrm{ng} / \mathrm{mL}$ did not induce a blockage of the cell cycle. Doxorubicin $(50 \mathrm{nM})$ was used as control marker as it induced an arrest in G2/M phase. HYSE induced early apoptosis at $2 \mathrm{ng} / \mathrm{mL}$ after $24 \mathrm{~h}$ treatment of HL-60 cells and the effect is dose dependent. The sponge genus Hyrtios is well known source of secondary metabolites and a number of tryptophan alkaloids have been reported from Pacific specimens collected in Fiji, Indonesia and the Okinawan Islands. A number of these alkaloids have demonstrated anti-bacterial, anti-malarial and cytotoxic activities [27]. Khokhar, et al. [27] reported the cytotoxicity activity of two new tryptophan alkaloids namely 6-oxo fascaplysin and secofascaplysic acid which displayed significant cytotoxicity activity against an androgensensitive prostate cancer cell-line (LNCaP) and non-malignant neonatal foreskin fibroblasts. Additionally, Hyrtios sp. extract was examined for anticancer activity against human colorectal carcinoma RKO cells that are wildtype for p53 and RKO-E6 that are p53 defective. The results indicated that Hyrtios sp. extract induced apoptosis via different pathways depending on p53 status and could be a good natural product for developing new anticancer drugs [28]. Recently, Novalla, et al. [29] published a mini-review in which the synthesis of indole alkaloids and the biological activities such as anti-cancer (including cell apoptosis), anti-oxidant, antifungal and anti-tuberculosis of secondary metabolites isolated from Hyrtios sp. are explicitly described [29].

vii) Epipolasis suluensis: The sponge Epipolasis suluensis can be found in Eastern Philippines, Southern Thailand, Easter Africa and Zanzibar, according to the World Porifera Database. Our research showed that the ethyl acetate extract (ESE) of the sponge evaluated by MTT assay had a cytotoxic activity of $66 \%$ on KB cells, $77 \%$ on HL- 60 cells and $72 \%$ on HepG 2 and $90 \%$ on MRC5 cells by MTT assat at $50 \mu \mathrm{g} / \mathrm{mL}$. Additionally, ESE displayed cytotoxic activity of $99 \pm 1 \%$ and $97 \pm 1 \%$ at $10 \mu \mathrm{g} / \mathrm{mL}$ and $1 \mu \mathrm{g} / \mathrm{mL}$ respectively on $\mathrm{KB}$ cells. Further investigation showed that ESE has $\mathrm{IC}_{50}$ values of $85 \mathrm{ng} / \mathrm{mL}$ on $\mathrm{KB}$ cells and $2.3 \mu \mathrm{g} / \mathrm{mL}$ on HL-60 cells respectively. It was found that at $24 \mathrm{~h}$ ESE elicited a moderate blockage of the cell cycle at high doses $(5,10$ and $20 \mu \mathrm{g} / \mathrm{mL})$ and at $48 \mathrm{~h}$ cells enter the apoptotic process and no further blockage was detectable. HL-60 cells enter early apoptosis and to smaller extent in late apoptosis with the highest doses tested. Kanazawa, et al. [30] reported the anti-fungal and anti-thrombin activities of the sponge Epipolasis $s p$ and the subsequent isolation of steroid sulfates. Umeyama, et al. [31] isolated three new diterpenes, polasols $\mathrm{A}-\mathrm{C}$, from the Japanese marine sponge Epipolasis $\mathrm{sp}$ and Suzuki, et al. [32] reported the isolation of spirastrellolides A and $\mathrm{B}$ from the sponge Epipolasis sp displaying $\mathrm{IC}_{50}$ values of 20 and $50 \mathrm{nM}$ respectively against HeLa cells. In 2018, Buttachon, et al. [33] identified a bis-indolyl benzenoid (Petromurin C) from an extract of $A$. candidus KUFA 0062 cultures, isolated from the sponge Epipolasis sp. Petromurin C significantly killed colorectal, liver, lung, breast and brain cancer cells. However, the mechanism of action has to be determined $[33,34]$.

viii) Biemna tubulata: The ethyl acetate extract (BTUE) of the sponge Biemna tubulata showed cytotoxicity greater than $70 \%$ against five cancer cell lines namely KB, HL-60, HeLa, A549 and PACA and $45 \%$ on MRC5 at $50 \mu \mathrm{g} / \mathrm{mL}$ by MTT assay. Additionally, BTUE displayed cytotoxic activity of $99 \%$ and at $86 \%$ at $10 \mu \mathrm{g} /$ $\mathrm{mL}$ and $1 \mu \mathrm{g} / \mathrm{mL}$ on $\mathrm{KB}$ by MTS assay respectively. The $\mathrm{IC}_{50}$ values of BTUE on $\mathrm{KB}$ and HL-60 were $0.5 \mu \mathrm{g} / \mathrm{mL}$ and $1.4 \mu \mathrm{g} /$ $\mathrm{mL}$ respectively. Further investigation on HL-60 showed that at 24h, BTUE elicited a moderate blockage of the cell cycle at high doses $(5,10$ and $20 \mu \mathrm{g} / \mathrm{mL})$ and at $48 \mathrm{~h}$ cells enter the apoptotic process and no further blockage was detectable. HL-60 cells enter early apoptosis and to smaller extent in late apoptosis with the highest doses tested. A number of research studies have been conducted on the genus Biemna. In 2014, Gros, et al.[35], reported the isolation of seven new tricyclic alkaloids, netamines $\mathrm{H}-\mathrm{N}$ (1-7) along with known netamine $\mathrm{G}$ and mirabilins A, C and $\mathrm{F}$. Netamine $\mathrm{M}$ has an $\mathrm{IC}_{50}$ in the micromolar range against $\mathrm{KB}$ cells and netamine $\mathrm{K}$ exhibited activity against Plasmodium falciparum with an $\mathrm{IC}_{50}$ value of $2.4 \mu \mathrm{M}$. Youssef, et al., [36] reported a new $\mathrm{C} 24$-acetylenic acid (biemnic acid) from the Red sea sponge Biemna ehrenbergi.

\section{Conclusion}

Out of 26 sponges studied, the ethyl acetate extracts of three species namely Epipolasis sp (ESE), Biemna tubulata (BTUE) and Hyrtios sp (HYSE) displayed significant activity at low concentrations. ESE and HYSE displayed $\mathrm{IC}_{50}$ values at nano-level concentrations on $\mathrm{KB}$ and HL-60 cancer cells. However, HYSE is more active and induces early apoptosis at $2 \mathrm{ng} / \mathrm{mL}$ after $24 \mathrm{~h}$ treatment of HL-60 cells and the effect is dose-dependent without blockage of the cell cycle. These three species are suitable candidates for further research involving chemical and pharmacological studies.

\section{References}

1. Hay ME, Fenical W (1996) Marine Biological Diversity: A Special Issue Commemorating 25 Years of Science and Service by the National Oceanic and Atmospheric Administration. Oceanography 9: 10-20.

2. Thomas TR, Kavlekar DP, LokaBharathi PA (2010) Marine drugs from spongemicrobe association--a review. Mar Drugs 8: 1417-1468. [Crossref]

3. Haefner B (2003) Drugs from the deep: marine natural products as drug candidates Drug Discov Today 8: 536-544. [Crossref]

4. Cheng MM, Tang XL, Sun YT, Song DY, Cheng YJ, et al. (2020) Biological and Chemical Diversity of Marine Sponge-Derived Microorganisms over the Last Two Decades from 1998 to 2017. Molecules 25: 853. 
5. Perdicaris S, Vlachogianni T, Valavanidis A (2013) Bioactive Natural Substances from Marine Sponges: New Developments and Prospects for Future Pharmaceuticals. Nat Prod Chem Res 1: 2329-6836.

6. Mehbub MF, Lei J, Franco C, Zhang W (2014) Marine sponge derived natural products between 2001 and 2010: trends and opportunities for discovery of bioactives. Mar Drugs 12: 4539-4577. [Crossref]

7. Pomponi SA (2001) The Oceanography Society Biennial Scientific Meeting. Oceanography 14: 78-87.

8. https://www.who.int/news-room/fact-sheets/detail/cancer

9. Sawyers C (2004) Targeted cancer therapy. Nature 432: 294-297. [Crossref]

10. Beedessee G, Ramanjooloo A, Aubert G, Eloy L, Surnam-Boodhun R, et al. (2012) Cytotoxic activities of hexane, ethyl acetate and butanol extracts of marine sponges from Mauritian Waters on human cancer cell lines. Environ Toxicol Pharmacol 34: 397-408. [Crossref]

11. Beedessee G, Ramanjooloo A, Surnam-Boodhun R, van Soest RW, Marie DE (2013) Acetylcholinesterase-inhibitory activities of the extracts from sponges collected in mauritius waters. Chem Biodivers 10: 442-451. [Crossref]

12. Ramanjooloo A, Cresteil T, Lebrasse C, Beedessee G, Oogarah P, et al. (2015) $\hat{\mathrm{I}} \pm$ Glucosidase inhibitory activity of marine sponges collected in Mauritius waters. Nat Prod Res 29: 383-387. [Crossref]

13. Becerro MA, Thacker RW, Turon X, Uriz MJ, Paul VJ (2003) Biogeography of sponge chemical ecology: comparisons of tropical and temperate defenses. Oecologia 135: 91 101. [Crossref]

14. Assmann M, Lichte E, Pawlik JR, Köck M (2000) Chemical defenses of the Caribbean sponges Agelas wiedenmayeri and Agelas conifera. Mar Ecol Prog Ser 207: 255-262.

15. Hardoko PD, Yuli E (2016) Anticancer potential of Seagrass leaves Cymodecea serrulata CRUDE extract on HeLa cell. $J$ Chem Pharm Res 8: 571-576.

16. Soeksmanto A, Subroto MA, Wijaya H, Simanjuntak P (2010) Anticancer activity tes for extracts of Sarang semut plant (Myrmecodya pendens) to HeLa and MCM-B2 cells. Pak J Biol Sci 13: 148-151. [Crossref]

17. Li Y, Huan J, Lin W, Yuan Z, Feng S, et al. (2016) New Dammarane-type Saponins from Gynostemma pentaphyllum. Evid-Based Compl Alt.

18. DiPaola RS (2002) To arrest or not to G(2)-M Cell-cycle arrest : commentary re: A K. Tyagi et al., Silibinin strongly synergizes human prostate carcinoma DU145 cells to doxorubicin-induced growth inhibition, G(2)-M arrest, and apoptosis. Clin. cancer res., 8: 3512-3519, 2002. Clin Cancer Res 8: 3311-3314. [Crossref]

19. Nurhayati APD, Pratiwi R, Wahyuono S, Fadlan A (2014) In Vitro Test and Molecular Docking of Alkaloid Compound in Marine Sponge Cinachyrella anomala against T47D Cell Cycle. J Adv Botany Zool.

20. Machida K1, Abe T, Arai D, Okamoto M, Shimizu I, et al. (2014) Cinanthrenol A, an estrogenic steroid containing phenanthrene nucleus, from a marine sponge Cinachyrella sp. Org Lett 16: 1539-1541. [Crossref]

21. Qaralleh H (2016) Chemical and bioactive diversities of marine sponge Neopetrosia. Bangl J Pharmac 11: 433-452.
22. Majali I, Qaralleh H, Idid S, Saad S, Susanti D, et al. (2015) Potential Antimicrobial Activity of Marine Sponge. J Basic Appl Res 1: 1-13.

23. Eltamany EE, Ibrahim AK, Radwan MM, ElSohly MA, Hassanean HA, et al. (2015) Anti-choline esterase activity of ceramides from the Red Sea marine sponge Mycale euplectellioides. Med Chem Res 24: 3467-3473.

24. Chevallier C, Laprévote O, Bignon J, Debitus C, Guénard D, et al. (2004) Isolation of cytotoxic chondropsins, macrolide lactams from the New-Caledonian marine sponge Psammoclemma sp. and electrospray ion trap multiple stage MS study of these macrolides. Nat Prod Res 18: 479-484. [Crossref]

25. Holland IP, McCluskey A, Sakoff JA, Gilbert J, Chau N, et al. (2009) Steroids from an Australian sponge Psammoclema sp. J Nat Prod 72: 102-106. [Crossref]

26. Ojika M, Itou Y, Sakagami Y (2003) Structural studies and antifungal activity of unique polyene amides, clathrynamide $\mathrm{A}$ and three new derivatives, from a marine sponge, Psammoclemma sp. Biosci Biotechnol Biochem 67: 1568-1573. [Crossref]

27. Khokhar S, Feng Y, Campitelli MR, Ekins MG, Hooper JN, et al. (2014) Isolation, structure determination and cytotoxicity studies of tryptophan alkaloids from an Australian marine sponge Hyrtios sp. Bioorg Med Chem Lett 24: 3329-3332. [Crossref]

28. Lim, H.K.; Bae, W.; Lee, H.S. and Jung, J. (2014) Effects of ginsenoside compound $\mathrm{K}$ combined with cisplatin on the proliferation, apoptosis and epithelial mesenchymal transition in MCF-7 cells of human breast cancer. BioMed Res Int pp. 561-568.

29. Novanna M, Ethiraj KR, Kannadasan S (2019) An Overview of Synthesis of Indole Alkaloids and Biological Activities of Secondary Metabolites Isolated from Hyrtios Species. Mini Rev Med Chem 19: 194-205. [Crossref]

30. Kanazawa S, Fusetani N, Matsunaga S (1992) Halistanol Sulfates A-E, New Steroid Sulfates, from a Marine Sponge, Epipolasis sp. Tetrahedron 48: 5467-5472.

31. Umeyama A, Machida M, Nozaki M, Arihara S (1998) Peroxypolasol and mugipolasol: two novel diterpenes from the marine sponge epipolasis sp J Nat Prod 61: 1435-1436. [Crossref]

32. Suzuki M, Ueoka R, Takada K, Okada S, Ohtsuka S, et al. (2012) Isolation of spirastrellolides A and B from a marine sponge Epipolasis sp. and their cytotoxic activities. J Nat Prod 75: 1192-1195. [Crossref]

33. Buttachon S, Ramos AA, Inacio A, Dethoup T, Gales L, et al. (2018) Bis-Indoly Benzenoids, Hydroxypyrrolidine Derivatives and Other Constituents from Cultures of the Marine Sponge-Associated Fungus Aspergillus candidus KUFA0062. Mar Drugs 16: 119 .

34. Ha YN, Song S, Orlikova-Boyer B, Cerella C, Christov C, et al. (2020) Petromurin C Induces Protective Autophagy and Apoptosis in FLT3-ITD-Positive AML: Synergy with Gilteritinib. Mar Drugs 18: 57.

35. Gros E, Al-Mourabit A, Martin MT, Sorres J, Vacelet J, et al. (2014) Netamines H-N, tricyclic alkaloids from the marine sponge Biemna laboutei and their antimalarial activity. J Nat Prod 77: 818-823. [Crossref]

36. Youssef DT, Badr JM, Shaala LA, Mohamed GA, Bamanie FH (2015) A new nucleoside and two new pyrrole alkaloid derivatives from Cordyceps militaris. Phytochem Lett 12: 296-301.

Copyright: (C2020 Roy P. This is an open-access article distributed under the terms of the Creative Commons Attribution License, which permits unrestricted use, distribution, and reproduction in any medium, provided the original author and source are credited. 